\title{
Inoculum production and inoculation of Gnetum africanum rooted cuttings using a range of mycorrhizal fungi
}

\author{
Eneke Esoeyang TAMBE BECHEM ${ }^{1 *}$ and Ian James ALEXANDER ${ }^{2}$ \\ ${ }^{1}$ Department of Plant and Animal Sciences, Faculty of Science, University of Buea, \\ P.O. Box 63 Buea, South West Region, Cameroon. \\ ${ }^{2}$ University of Aberdeen, School of Biological Sciences, Plant and Soil Sciences, \\ Cruickshank Building, Aberdeen AB24 $3 U U$. \\ * Corresponding author, E-mail: tamenekeso@yahoo.co.uk
}

\begin{abstract}
We studied the ability of peat/vermiculite, barley, rye grain, baby corn and nitrocellulose filter paper to serve as carriers for inoculum production using an isolate of Scleroderma sinnamariense, Scleroderma sp., Paxillus involutus and three isolates of Pisolithus tinctorius. Soil collected from the vicinity of some ectomycorrhiza tree species, mycorrhiza root tips, mycelium and spores of $S$. sinnamariense were also tested as inoculum. Inoculation of Gnetum rooted cuttings was by the use of both dried and fresh sporocarps of the fungus as well as by use of inoculum prepared on the carriers mentioned above. All fungal isolates showed some growth on peat/vermiculite, barley, rye grain, baby corn and nitrocellulose filter paper. The Paxillus and Pisolithus isolates grew better on these carriers as compared to the Scleroderma isolates. The use of viable root tips, mycelium and spores of $S$. sinnamariense led to the formation of ectomycorrhiza on the previously uncolonized plants. This method can be successfully used to produce ectomycorrhizal Gnetum rooted cuttings, which may be used for outplanting thereby increasing their chances of survival.
\end{abstract}

(c) 2009 International Formulae Group. All rights reserved.

Keywords: Scleroderma sinnamariense, Pisolithus, Paxillus, ectomycorrhiza, inoculum production.

\section{INTRODUCTION}

Gnetum africanum and $G$. buccholzianum are gymnosperm lianas found in the forests of Cameroon as well as in other countries of Central and West Africa. The leaves are used as a vegetable and are a good source of proteins and mineral salts (Fokou and Domngang, 1989; Mialoundama, 1993). These plants have also been shown to have important ethnopharmacological uses (Robyns, 1948; Watt and Breyer-Brandwijk, 1962; Bouquet, 1969; Lowe, 1984; Schultes and Raffauf, 1990; Paru et al., 1995).

The collection and sale of Gnetum leaves is important in the cross border trade between Cameroon and its neighbours as well as with Europe and the United States of
America. This plant which is in high demand yields a profit margin of about $\$ 2,630$ per year per household (Fondoun and Manga, 2000). The overexploitation of the plant and the unsustainable harvesting methods puts this plant at risk of extinction. With the current and steady decline in area of forests in West and Central Africa, supplies of Gnetum spp. are becoming scarce (Shiembo et al., 1996). There is a need therefore, to look for ways to improve cultivation of the plant.

Gnetum spp. are reported to form ectomycorrhiza (EM) (Mialoundama and Mbou, 1992; Ingleby, 1999; Onguene and Kuyper, 2001). Mycorrhiza is a symbiotic association formed by some soil inhabiting fungi and the roots of higher plants. In this 
relationship, the fungus receives photosynthetically derived carbon compounds from the plant. The plant in turn benefits by increased uptake of mineral nutrients, possibly improved disease and toxin resistance as well as water relations (Smith and Read, 1997). Two major types of mycorrhizal associations exist depending on the position of the fungus in relation to the root surface: ectomycorrhizas with intercellular colonization and endomycorrhizas with both inter- and intracellular colonization (Smith and Read, 1997).

Establishment of Gnetum plantations in Cameroon, which are expected to reduce pressure on the wild stock, is desirable. It is envisaged that successful domestication will depend partly on mycorrhization of the rooted cuttings before outplanting. However for this to occur, information on the potential and actual fungal partners is needed. A method of inoculation will also be vital.

Devising methods to synthesise mycorrhizas is also essential to provide experimental material to investigate the physiology of the symbiosis, and the role of EM colonization in the growth and nutrition of Gnetum. Attempting inoculum production on different substrates and the use of different techniques would give an indication of the capacity of $S$. sinnamariense to withstand the physical, chemical and biological manipulations involved.

Mycorrhizas can be synthesised by bringing seedlings of host plants and EM fungi inoculum close to each other in a favourable growth environment. Synthesis has been achieved through several different methods, using both sterile and non sterile techniques (Fortin et al., 1983; Wong and Fortin, 1989; Burgess et al., 1994). The advantages and shortcomings of the different techniques have been discussed by Peterson and Chakravarty (1991).

In all the inoculation trials described in this paper, non-sterile techniques were used. It was difficult to get sterile plants because of the method of propagation employed in their production. Our major interest was to look at compatibility and mycorrhiza formation under circumstances as close to that in nature as possible. Cuttings were used in this experiment because of the difficulties in germinating Gnetum seeds. To date, no published literature exists on the production of inoculum using Gnetum ectomycorrhiza fungi associates and synthesis of EM with Gnetum. Presently in some research institutions in Cameroon, for example the Limbe Botanic Garden and at International Centre for Agroforestry Research (ICRAF), Gnetum rooted cuttings used in domestication trial experiments are inoculated by planting in rhizosphere and bulk soil collected from the natural habitat of the plant for some time in the nursery, prior to outplanting. With this method of inoculation only a limited number of mycorrhizal plants can be produced because of the difficulties involved in obtaining inoculum. It is therefore imperative that other methods of inoculation be studied.

Pisolithus tinctorius and Paxillus involutus, two broad host range EM fungi were included in these inoculation experiments.

The main objective was to synthesize mycorrhizas by inoculating rooted Gnetum cuttings with pure mycelial cultures or spores of EM.

The specific objectives were to evaluate;

- The ability of Gnetum to form mycorrhizas with broad host range EM fungi.

- The potential of different substrates to support growth of the EM fungal associates of Gnetum (inoculum production).

- Different methods of inoculation.

- The possibility of forming arbuscular mycorrhiza (AM) on Gnetum using Gigaspora margarita and Glomus mosseae, which are broad host range and widespread fungi.

- EM synthesis attempts between Hopea odorata and Scleroderma sinnamariense.

\section{MATERIALS AND METHODS}

These experiments were run in the screen house at the Department of Plant and Soil Sciences, University of Aberdeen, Scotland, United Kingdom.

\section{Production of Gnetum rooted cuttings}

The propagation method adopted here was based on Shiembo et al. (1996) but with slight modifications. The Gnetum stock plants were kept in a phytotron with a relative humidity of $85 \%$, temperature $26{ }^{\circ} \mathrm{C}$ and a 
photoperiod of $8 \mathrm{~h}$ darkness and $16 \mathrm{~h}$ light. Plants were watered as required. The plants were held under these conditions for about two months prior to the propagation experiment. Propagation was carried out in a heated bench top non-mist propagator. The propagator consisted of a tray about $60 \mathrm{~cm}$ long, $32 \mathrm{~cm}$ wide and a depth of $8 \mathrm{~cm}$. The tray had a lid made of transparent polythene. The rooting medium was peat $\left(\mathrm{SHAMROCK}^{\mathrm{TM}}\right)$ mixed with coarse sand (washed concrete sand) in a 1:1 ratio. The coarse sand had initially been washed several times with tap water followed by decantation between successive washings. The rooting medium was used to fill the tray to the brim and watered to field capacity. The temperature in the propagator was set at $25{ }^{\circ} \mathrm{C}$. A total of 60 half-leaf cuttings were used in the propagation. Watering was done as required by use of a fine sprayer. Plants were observed for any signs of rooting fortnightly, thereafter observations continued after every four weeks for the rest of the 16 weeks experimental period.

\section{Inoculum production and synthesis attempts}

Rooted cuttings were used in synthesis experiments only after they had developed sufficient numbers of lateral roots (visual appreciation). The origin, host plant and species of EM fungi used in the inoculation trial experiment are shown on table 1.

The following carriers and techniques were used in the synthesis of ectomycorrhizas with Gnetum rooted cuttings;

- Inoculum production and synthesis using peat/vermiculite.

- Inoculum production and synthesis using natural substrates (barley, rye grain and baby corn).

- Synthesis using mycelium inoculum on filter paper.

- Synthesis using soil inoculum.

- Synthesis using spores, mycorrhiza root tips and mycelium of $S$. sinnamariense.

Inoculum production and EM inoculation of Gnetum using peat/vermiculite

All the EM fungi: Paxillus, Pisolithus and the two Scleroderma isolates were initially held on Modified Melin Norkran (MMN) (Marx, 1969) agar plates.
The methodology used in inoculum production was based on that of Marx and Bryan (1975). Each isolate was run in three replicates. The $\mathrm{pH}$ of the carrier prior to and after autoclaving was 5.4. Incubation was at $30{ }^{\circ} \mathrm{C}$ for all Pisolithus isolates and $S$. sinnamariense whilst the Paxillus involutus and Scleroderma collected from Aberdeen were incubated at room temperature (10-15 ${ }^{\circ} \mathrm{C}$ ) for 6-8 weeks. A peat/sand mixture in a 1:1 ratio was used as potting medium during inoculation. Two methods of inoculation were carried out. One in which the inoculum was incorporated in an 8:1 ratio through out the potting medium and another in which the mycorrhizal inoculum was banded in the potting medium. Each fungus isolate was run in three replicates for each inoculation procedure. Plants were kept for 16 weeks on a bench top in the greenhouse with temperature of $25-30{ }^{\circ} \mathrm{C}$, relative humidity of about $85 \%$ and a photoperiod of $8 \mathrm{~h}$ dark and $16 \mathrm{~h}$ light. Watering was done as required.

Inoculum production and EM inoculation of Gnetum using inoculum on natural substrate

The substrates were chosen arbitrarily based on availability. In the process of inoculum production, $2 \mathrm{~g}$ of barley straw (about $1 \mathrm{~cm}$ in length) moistened with $20 \mathrm{ml}$ of $1 \%$ glucose solution was autoclaved at 121 ${ }^{\circ} \mathrm{C}$ for 30 minutes in $100 \mathrm{ml}$ Erlenmeyer flasks. Prior to autoclaving, the $\mathrm{pH}$ of mixture was adjusted to 5.0, flasks capped with cotton wool and aluminium foil. Contents were allowed to cool to room temperature before inoculation under sterile conditions with 8 fungal mycelia discs (5 $\mathrm{mm}$ diameter) cut from the edge of actively growing mycelia from each of the different fungal isolates, held on MMN agar plates.

$2 \mathrm{~g}$ of baby corn was chopped into bits of about $0.5-1 \mathrm{~cm}$ in diameter and processed as described for barley straw above. $2 \mathrm{~g}$ of rye grain was also processed in the same manner. Incubation was at $30{ }^{\circ} \mathrm{C}$ in the dark for $6-8$ weeks.

EM synthesis with Gnetum using paperbased inoculum in perspex plates

Inoculum production was by the method described in Chilvers et al. (1986). Incubation was at $30{ }^{\circ} \mathrm{C}$ in the dark 
Table 1: The species, origin and host of six ectomycorrhizal fungi isolates used in in vitro synthesis trials.

\begin{tabular}{llll}
\hline Species & Host & Origin & Ref. code \\
\hline Paxillus involutus & Larix sp. & United Kingdom & P1014 \\
Pisolithus tinctorius & Pinus sp. & Thailand & Pt msn \\
Pisolithus tinctorius & Acacia mangium & Senegal & Pt COI32 \\
Pisolithus tinctorius & Pinus sp. & Australia & Pt John Cairney \\
Scleroderma sinnamariense & Gnetum africanum & Cameroon & Scleroderma \\
Scleroderma sp. & Tilia & Aberdeen- Scotland & Scleroderma fence \\
\hline
\end{tabular}
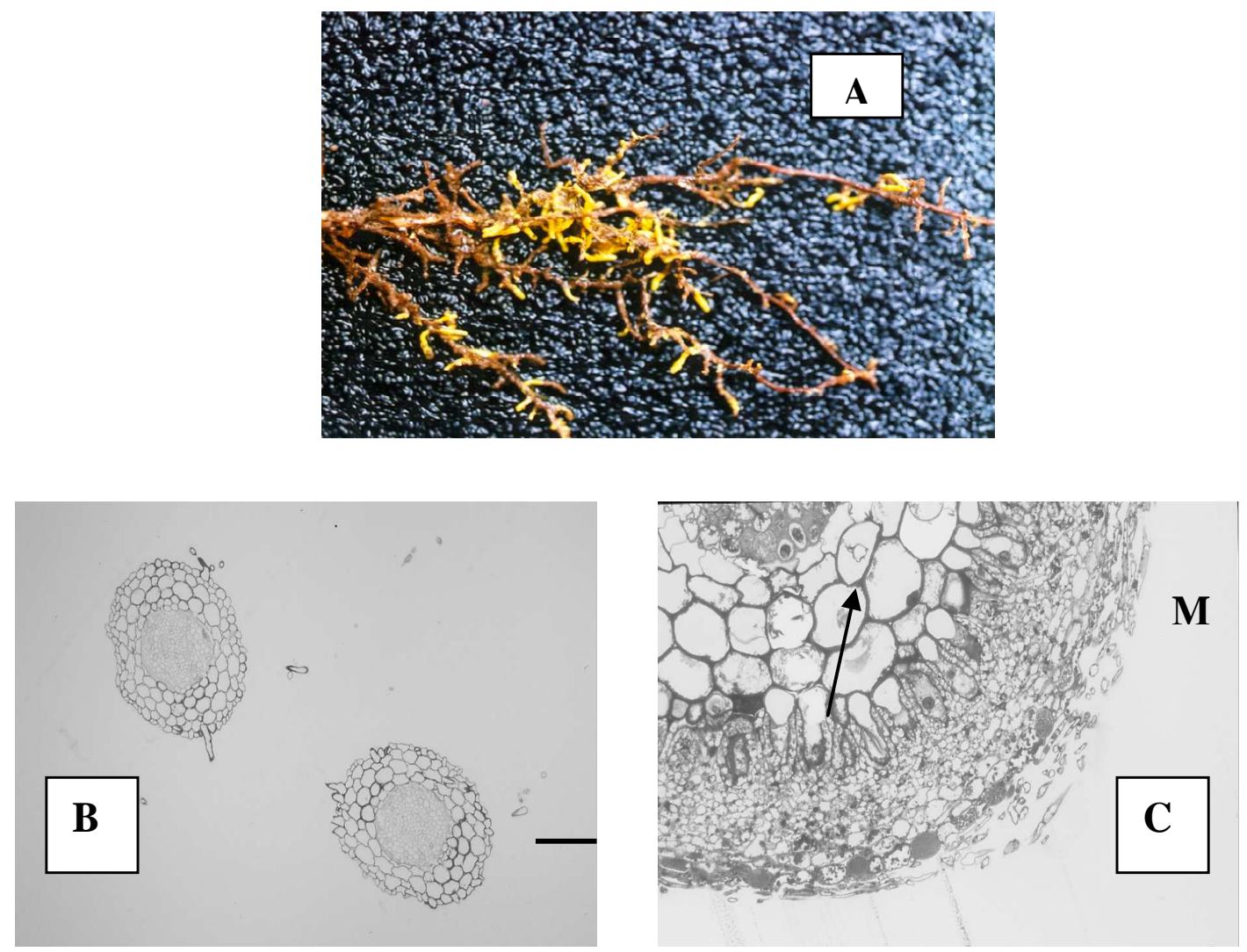

Plate 1: Synthesized Gnetum ectomycorrhizas. (A) Gnetum africanum + Scleroderma sinnamariense. (B) transverse section of nonmycorrhizal Gnetum root (C) transverse section of ectomycorrhizal Gnetum root. M shows the Mantle and arrow shows the Hartig net. Bar in B is $60 \mu \mathrm{m}$ while that in $\mathrm{C}$ is $20 \mu \mathrm{m}$.

for 4 weeks. Inoculation of cuttings was done in Perspex plates using the method of Finlay and Read (1986). Watering was done as required and plants were held in this condition for 4 weeks before introduction of the fungal inoculum. This was to stabilise and allow for further development of lateral roots. Incubation following inoculation was for 16 weeks. Eight replicate plates were run. During observation, upper sheet of plate and 
inoculum paper were carefully removed, before examination of roots using stereo and compound microscopes where necessary.

Fungal growth in all carriers was evaluated by visual observation and by the use of a stereomicroscope. The presence of mycelia of the fungus around and within the carrier was an indication of growth. In the process of assessing growth within the carrier, a small portion of the carrier containing fungal mycelium was aseptically collected, placed in a Petri dish and observed for the presence of mycelium within the carrier with the aid of a stereomicroscope.

\section{EM inoculation of Gnetum using soil inoculum}

Decomposing material from the soil surface containing abundant ectomycorrhizal roots was collected from beneath birch (Betula pendula), beech (Fagus sylvatica) and Scots pine (Pinus sylvestris) growing in Aberdeenshire, UK. The material was combined and passed through a coarse $(1 \mathrm{~cm})$ sieve. Soil was processed and used in inoculation, within 72 hours of collection. The sieved mixture was added to pre-washed sand in a 1:1 ratio. This was then used to pot rooted Gnetum cuttings in $15 \times 15 \mathrm{~cm}$ F free-draining plastic pots. An uninoculated control was run, in which a portion of the sieved soil was sterilised twice at $121^{\circ} \mathrm{C}$ for $1 \mathrm{~h}$ with a $24 \mathrm{~h}$ period between the two sterilisations. The sterilised soil and washed sand were mixed in a 1:1 ratio. The resulting mixture was used to pot Gnetum cuttings. There were a total of eight inoculated and eight control plants. Incubation was in the greenhouse for 16 weeks. Watering was done as required. During observation, a pot was tipped over and removed from the soil; roots were then observed with the aid of a hand lens for any signs of colonization. At the end of the experiment, roots were carefully separated and washed free of soil before observing both visually and microscopically based on method described in Brundett et al. (1996).

\section{EM inoculation of Gnetum using root fragments}

Mycelia and mycorrhizal root systems were harvested from roots and the vicinity of established Gnetum potted plants, colonized by Scleroderma sinnamariense. During inoculation, each pot containing an assay plant was turned upside down; pot removed leaving the plant with the intact root system held in the growth medium. A mycorrhizal system with viable tips and mycelia collected from the ectomycorrhizal plant was placed in close proximity to ultimate lateral roots (targets for mycorrhization) of the test plant. Test plants were then carefully placed into pots and watering was done as required. A total of eight plants were inoculated with ectomycorrhizal system and mycelium. Incubation was in the greenhouse for 16 weeks and watering was done as required. Observation was done as previously explained.

\section{EM inoculation of Gnetum using spores}

Fresh sporocarps of $S$. sinnamariense were collected from the vicinity of the ectomycorrhizal Gnetum plant. Each sporocarp was cut into two halves to expose the spores and each half was placed in contact with lateral roots of Gnetum plant in freedraining plastic pots $(15 \times 15 \mathrm{~cm} \quad \mathrm{~F})$. Inoculation was also done by use of dried spores of $S$. sinnamariense. This was simply by breaking the dried sporocarp containing mature spores and putting both spores and peridium into the pot close to the roots of test plants. Four plants were inoculated with fresh sporocarps and four with dried spores. This brought the total to eight plants in the experiment. Plants were watered as required and incubation was for a 16 weeks period in the green house. Observation was done at the end of the incubation period.

\section{Inoculation of Gnetum with AM fungi}

The fungi isolates used here were Glomus mosseae (BEG 12) and Gigaspora margarita (BEG 34). They were from the European Bank of Glomales. The fungi were held in pot cultures of steamed sand (autoclaved twice at $121{ }^{\circ} \mathrm{C}$ for 1 hour with 24 hours between sterilisation) with Sorghum sp. as host plant. The inoculum obtained therefore consisted of spores held in a fine sand mix. The potting medium for the Gnetum plants was peat/sand 1:1. Medium was autoclaved for $1 \mathrm{~h}$ at $121{ }^{\circ} \mathrm{C}$. It was then allowed to cool for $24 \mathrm{~h}$, followed by a second autoclaving session for the same period of time and temperature. Sterile medium was used to fill 
free-draining pots $(12.7 \times 12.7 \mathrm{~cm} \mathrm{~F})$. During inoculation, a planting hole was made in each pot, and one tablespoonful of inoculum mix of either Gigaspora or Glomus species was added into the planting hole prior to the introduction of the plant. Six plants were inoculated with each fungus species resulting to a total of twelve plants used in the experiment. Incubation was for a 16 weeks period in the greenhouse. Plants were watered as required. After 16 weeks of growth, root samples were collected from plants initially inoculated with Glomus and Gigaspora and observation for $\mathrm{AM}$ was as described in Brundett et al. (1996).

EM synthesis between Hopea sp. and $S$. sinnamariense

The purpose of this experiment was to have an idea as to whether $S$. sinnamariense from Gnetum in Cameroon could form mycorrhiza with Hopea odorata from Malaysia. We used two years old Hopea sp. rooted cuttings. The rooted cuttings were nonmycorrhizal and this was confirmed by microscopy of free hand sections as well as cleared and stained roots. The experimental potting medium was a 1:1 mixture of peat/sand. Potting medium was used to fill free-draining pots $(9 \times 9 \mathrm{~cm} \mathrm{~F})$. Viable ectomycorrhizal root systems and mycelia were collected from a well established Gnetum plant colonized with $S$. sinnamariense from Cameroon. A combination of ectomycorrhizal root fragments and mycelium were placed in the vicinity of the roots of the Hopea seedlings during potting. Twenty Hopea seedlings were inoculated in the experiment. Incubation was in the greenhouse for 16 weeks. Plants were watered as required.

At the end all mycorrhizal synthesis experiments, roots were sampled for colonization using method described in Brundett et al. (1996). Confirmation of colonization was by making free hand sections of suspected EM root tips and observing for the presence of a mantle and/or Hartig net.

\section{RESULTS}

At the end of the 16 weeks, Gnetum cuttings which had not rooted had at least developed a callus. Out of the 60 cuttings used in the propagation, 41 developed roots within this period, giving a total rooting percentage of $68.3 \%$. Enough rooted cuttings were therefore available to run the inoculation experiment.

\section{Inoculum production}

At the end of the 8 weeks incubation period, mycelium from each fungus isolate had grown into the vermiculite/peat substrate, barley, rye grain, baby corn and nitrocellulose filter paper. However growth of the Scleroderma isolates was poor relative to the Pisolithus and Paxillus isolates. S. sinnamariense showed extremely limited growth in barley, rye grain and baby corn, but grew well on nitrocellulose paper placed on MMN agar.

\section{Mycorrhiza synthesis}

Inoculation of Gnetum was possible with the use of root fragments collected from the vicinity of already established ectomycorrhizal Gnetum plants. At the end of the experimental period, all eight plants had formed ectomycorrhizas with the fungus. Ectomycorrhizas were observed as early as six weeks after inoculation. Mycorrhiza tips and mycelium had the characteristic bright yellow coloration (Plate 1) which is usually observed on this fungus-plant association in nature. The mycorrhiza had a well developed mantle and Hartig net (Plate 1). Inoculation was also possible with the use of spores of $S$. sinnamariense. At the end of the experimental period, all eight plants had formed ectomycorrhiza with the fungus. Mycorrhizas were established as early as 8 weeks. The mycorrhizas had a bright yellow coloration with a well developed mantle and Hartig net. Gnetum did not form mycorrhizas with the Paxillus and Pisolithus isolates used in this study. Mycorrhiza synthesis using paperbased inoculum on Perspex plates was also impossible with all the isolates tested. The fungal species present in the soil inoculum were unable to initiate mycorrhiza formation with Gnetum.

Gnetum did not form arbuscular mycorrhizas with the Glomus and Gigaspora species used in this study. The cleared and stained roots had no arbuscules, vesicles or hyphal coils which are characteristic features of this type of mycorrhiza. 
EM synthesis between Hopea sp. and $S$. sinnamariense

The Hopea plant was unable to form mycorrhizas with $S$. sinnamariense from Cameroon. All twenty Hopea plants still had non-mycorrhizal roots at the end of the experiment. Cleared and stained root sections showed neither a mantle nor Hartig net which are features characteristic of ectomycorrhizas.

\section{DISCUSSION}

It was demonstrated during this study that Gnetum spp. are predominantly ectomycorrhizal. Mycorrhiza formation was possible only with Scleroderma sinnamariense, a natural fungal partner to the plant. Mycorrhization could be achieved prior to outplanting by a simple method requiring the use of mycorrhiza tips, mycelia and spores of the fungus. The sustainability of this method is due to the fact that sterile conditions and other additional technical know-how are not necessary. Furthermore, in this method root tips and mycelia from one mycorrhizal plant could be used to inoculate about 30 or more rooted cuttings, resulting in the use of less soil inoculum which is bulky, time consuming and expensive, with possible introduction of pathogens. It is important to note that the use of soil inoculum is not feasible in large scale production systems. However more of such studies need to be carried out before an effective, reproducible and reliable method of inoculum production and inoculation is adopted for Gnetum.

There are several possible reasons for the inability of $S$. sinnamariense grown on nitrocellulose paper and peat/vermiculite to colonize Gnetum. The paper may have been rapidly colonized by bacteria hence reducing the inoculum potential of the fungus. The fungus may have lost its viability before colonization of the roots could commence. The inoculum potential on peat/vermiculite may have been low due to the poor growth of the fungus on this carrier. This is possible because at the time of inoculation, the fungus had not thoroughly colonized the carrier. A longer incubation time may be needed for inoculum production with this fungus since it grows slowly. This would allow the fungus to thoroughly colonize the substrate. Marx and Kenney (1982) reported that the length of incubation following inoculation of substrate with the fungus depended on the rate of growth of the fungus species. They found that fast-growing fungi like Thelephora terrestris and Pisolithus tinctorius totally colonized the substrate in 2-litre containers in 2-3 months whereas slow-growing fungi such as Cenococcum geophilum would take up to 8-10 months to colonize the same amount of substrate. It is also possible that the fungus could not stand the physical handling involved in processing the inoculum.

In spite of the fact that the Pisolithus and Paxillus species in the current study had totally colonized the carrier prior to inoculation of the plant, there was no EM formation. The absence of colonization of Gnetum by these species is probably due to lack of compatibility. Gnetum shows seemingly strict host-fungus specificity and has mostly been associated with $S$. sinnamariense. Nonetheless it was found during a related field survey, that it also does form EM with another fungus which we suspect to be a Scleroderma sp. But $S$. sinnamariense was the most prevalent and widespread fungal partner of Gnetum spp. in Cameroon.

The limited growth of $S$. sinnamariense on rye grain, baby corn and barley straw may be due to several reasons. One possibility is that growth inhibitors may have been released during autoclaving. Similarly a lack of growth by typically fast growing fungi such as Pisolithus tinctorius and Thelephora terrestris on peanut hulls, perlite, corn cobs and pine barks has been observed as reported by Marx and Kenney (1982).

The failure of Gnetum to form arbuscular mycorrhizas with Glomus and Gigaspora is surprising. This is because about $90 \%$ of land plants form AM with these fungal species (Smith and Read, 1997). Another reason is that Gnetum always harbours ectomycorrhiza even when growing amongst Chromolaena odorata, which is a plant that forms AM. Such an observation, points to the fact that Gnetum might be strictly ectomycorrhizal. Members of the Gnetaceae have always been reported to form ectomycorrhizas (Fassi, 1957; St. John, 1980b; Smith and Read, 1997), although Onguene (2000) reported the occasional observation of AM structures in some Gnetum root fragments collected from South 
Cameroon. His observation may just have been a 'one-off'. This was most likely because our survey of Gnetum mycorrhiza carried out in the same study site as Onguene (2000) gave observations contrary to his.

$S$. sinnamariense is a pan-tropical fungus which has been associated with Gnetum spp. in Africa and with dipterocarps in Asia (Fassi, 1957; Sims et al., 1997). In Malaysia it has been associated with Hopea odorata, whilst in the Philippines it is associated with Anisoptera sp., Dipterocarpus grandifloris and Shorea polysperma (Sims et al., 1997). This fungus has a widespread distribution in major tropical forests, a reason why it is thought to have been given many different names (Sims et al., 1997). In the course of this study, we were curious as to whether S. sinnamariense from Gnetum in Cameroon could form mycorrhiza with Hopea odorata from Malaysia.

In spite of the fact that Hopea is an ectomycorrhizal plant associated with $S$. sinnamariense in Malaysia, there was no mycorrhization between the test fungal isolate (S. sinnamariense) and Hopea. There are several possible reasons for such an observation. The most probable reason is that the fungus described as $S$. sinnamariense in Africa is different from the fungus with the same name in Asia.

For the establishment of farms and plantations, it is absolutely necessary to look for a cheaper, sustainable and more reliable method of inoculating plants before outplanting. However at the end of this study, we were able to produce ectomycorrhizal rooted Gnetum cuttings which were used to carry out other physiological studies on this host/fungus relationship.

\section{ACKNOWLEDGEMENTS}

We are thankful to Prof. Lee Su See of the Forest Research Institute Malaysia (FRIM) for providing Hopea Plants. We also like to acknowledge Prof. Roger Leakey for giving us Gnetum plants. We are grateful to Dr. Neree Onguene Awana of IRAD Nkolbisson for assitance. We also thank the anonymous reviewers for their suggestions and comments. Our gratitude goes to the Association of Commonwealth Universities for the financial support.

\section{REFERENCES}

Bouquet A. 1969. Feticheurs et medicines traditionnelles du Congo (Brazzaville). Memoire O.R.S.T.O.M., 36.

Brundett MC, Bougher N, Dell B, Grove T, Malajczuk N. 1996. Working with Mycorrhizas in Forestry and Agriculture. ACIAR Monograph: Canberra; 32.

Burgess T, Dell B, Malajczuk N. 1994. Variations in mycorrhizal development and growth stimulation by 20 Pisolithus isolates inoculated on to Eucalyptus grandis W. Hill ex Maiden. New Phytologist, 127: 731-739.

Chilvers GA, Douglass PA, Lapeyrie FF. 1986. A paper-sandwich technique for rapid synthesis of ectomycorrhizas. New Phytologist, 103: 397-402.

Fassi B. 1957. Ectomycorrhizes chez Gnetum africanum Welw. due à un Scleroderma sp. Bull. Soc. Mycol Fr., 73: 280-286.

Finlay RD, Read DJ. 1986. The structure and function of the vegetative mycelium of ectomycorrhizal plants. I. Translocation of ${ }^{14} \mathrm{C}$-labelled carbon between plants interconnected by a common mycelium. New Phytologist, 103: 143-156.

Fokou E, Domngang F. 1989. In vivo assessment of the nutritive value of proteins in situ in the leaves of Solanum nigrum L., Xanthosoma spp. and Gnetum africanum L. Indian Journal of Nutrition and Dietetics, 26(12): 366-373.

Fondoun JM, Manga TT. 2000. Farmers indigenous practices for conserving Garcinia kola and Gnetum africanum in Southern Cameroon. Agroforestry systems, 48(3): 289-302.

Fortin JA, Piche Y, Godbout C. 1983. Methods of synthesizing ectomycorrhizas and their effect on mycorrhizal development. Plant and Soil, 71: 275284.

Ingleby K. 1999. Scleroderma sinnamarense Mont. + Gnetum africanum Welw. Descr. Ectomyc., 4: 127-133.

Lowe J. 1984. Gnetum in West Africa. Nigerian Field, 49(1-4): 99-104.

Marx DH. 1969. The influence of ectotrophic mycorrhizal fungi on resistance of pine roots to pathogenic infections. I. Antagonism of mycorrhizal fungi to root pathogenic fungi and soil bacteria. Phytopathology, 59: 153-163. 
Marx DH, Bryan WC. 1975. Growth and ectomycorrhizal development of loblolly pine seedlings in fumigated soil infested with the fungal symbiont Pisolithus tinctorius. Forest Science, 21: 245-254.

Marx DH, Kenney DS. 1982. Production of ectomycorrhiza fungus inoculum. In Methods and Principles of Mycorrhizal Reasearch, Schenck NC (ed). American Phytopathological Society: St Paul, Minnesota; 131-146.

Mialoundama F. 1993. Nutritional and socioeconomic value of Gnetum leaves in Central African forest. In Tropical Forests People and Food: Biocultural Interactions and Applications to Development. Parthenon Publishing Group: Carnforth, UK.

Mialoundama F, Mbou R. 1992. Influence de la fertilisation minérale sur la croissance et sur le rythme d'émergence foliare de Gnetum africanum Welw. L'Agronomie Tropicale, 46(2): 89-96.

Onguene NA. 2000. Diversity and Dynamics of Mycorrhiza Associations in Tropical Rain Forests with different Disturbance Regimes in South Cameroon. Ph.D thesis Wageningen University, Wageningen, 25.

Onguene NA, Kuyper TW. 2001. Mycorrhiza associations in the rain forest of South Cameroon. Forest Ecology and Management, 140: 277-287.

Paru R, Hii J, Lewis D, Alpers MP. 1995. Relative repellency of wood smoke and topical applications of plant products against mosquitoes. Papua New Guinea Medical Journal, 38(3): 215-221.
Peterson RL, Chakravarty P, 1991. Techniques for synthesizing ectomycorrhiza. In Methods in Microbiology. Techniques for the Study of Mycorrhiza, Norris JR, Read DJ, Varma AK (eds). Academic Press: London; 75-106.

Robyns W. 1948. Gnetaceae. Flore du Congo Belge et du Ruanda-Urundi, 1; 4.

Schultes RE, Raffauf RF. 1990. The Healing Forest: Medicinal and Toxic Plants of the Northwest Amazonia. Dioscorides Press: Portland, OR.

Shiembo PN, Newton AC, Leakey RRB. 1996. Vegetative propagation of Gnetum africanum Welw., a leafy vegetable from West Africa. Journal of Horticultural Science, 7: 149-155.

Sims K, Watling R, De la Cruz R, Jeffries P. 1997. Ectomycorrhizal fungi of the Phillipines: a preliminary survey and notes on the geographic biodiversity of the Sclerodermatales. Biodiversity and Conservation, 6: 45-58.

Smith SE, Read DJ. 1997. Mycorrhiza Symbiosis $\left(2^{\text {nd }}\right.$ edn). Academic Press: London.

St. John TV. 1980b. A survey of mycorrhizal infections in an Amazonian rain forest. Acta Amazonica, 10: 527-533.

Watt JM, Breyer-Brandwijk MG. 1962. The Medicinal and Poisonous Plants of Southern and Eastern Africa ( $2^{\text {nd }}$ edn). Livingstone: Edinburgh and London.

Wong KY, Fortin JA. 1989. A petri dish technique for the aseptic synthesis of ectomycorrhizae. Can. J. Bot., 67: 17131716. 